\title{
8th AfrEA International Conference edition editorial
}

\begin{tabular}{|c|c|}
\hline $\begin{array}{l}\text { Authors: } \\
\text { Mark Abraham } \\
\text { Florence E. Ett } \\
\text { Michele Tarsill } \\
\text { Kambidima Wc }\end{array}$ & $\begin{array}{l}\mathrm{ns}^{1} \\
\mathrm{a}^{2} \\
\mathrm{a}^{3} \\
\text { otele }^{4}\end{array}$ \\
\hline \multicolumn{2}{|c|}{$\begin{array}{l}\text { Consulting and Development } \\
\text { Services, Cape Town, } \\
\text { South Africa }\end{array}$} \\
\hline \multicolumn{2}{|c|}{$\begin{array}{l}{ }^{2} \text { GRAIDE International } \\
\text { Development Evaluation } \\
\text { Consulting, Lagos, Nigeria }\end{array}$} \\
\hline \multicolumn{2}{|c|}{$\begin{array}{l}\text { 3international Development } \\
\text { Evaluation Association } \\
\text { (IDEAS), France, Italy }\end{array}$} \\
\hline \multicolumn{2}{|c|}{$\begin{array}{l}{ }^{4} \text { Monitoring and Evaluation, } \\
\text { WITS School of Governance } \\
\text { (WSG), South Africa }\end{array}$} \\
\hline \multicolumn{2}{|c|}{$\begin{array}{l}\text { Corresponding author: } \\
\text { Mark Abrahams, } \\
\text { marka@iafrica.com }\end{array}$} \\
\hline \multicolumn{2}{|c|}{$\begin{array}{l}\text { How to cite this article: } \\
\text { Abrahams, M., Etta, F.E., } \\
\text { Tarsilla, M. \& Wotela, K., } \\
\text { 2018, '8th AfrEA International } \\
\text { Conference edition editorial', } \\
\text { African Evaluation Journal } \\
\text { 6(1), a330. https://doi. } \\
\text { org/10.4102/aej.v6i1.330 }\end{array}$} \\
\hline \multicolumn{2}{|c|}{$\begin{array}{l}\text { Copyright: } \\
\text { (c) 2018. The Authors. } \\
\text { Licensee: AOSIS. This W } \\
\text { is licensed under the } \\
\text { Creative Commons } \\
\text { Attribution License. }\end{array}$} \\
\hline \multicolumn{2}{|l|}{ Read online: } \\
\hline 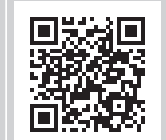 & $\begin{array}{l}\text { Scan this QR } \\
\text { code with your } \\
\text { smart phone or } \\
\text { mobile device } \\
\text { to read online. }\end{array}$ \\
\hline
\end{tabular}

The biennial conference of the African Evaluation Association (AfrEA) is a celebration of the achievements of evaluators and monitoring and evaluation (M\&E) practitioners on the African continent. The 8th AfrEA international conference held in Kampala, Uganda, in March 2017 was no exception. Hosted by the Uganda Evaluation Association (UEA), the conference, under the theme 'Evaluation of the Sustainable Development Goals (SDGs): Opportunities and Challenges for Africa', brought together delegates from 36 different African countries and other delegates from 35 different international destinations.

Some of the critical challenges for voluntary organisations of professional evaluators (VOPEs) and individual evaluators in the evaluation of the SDGs highlighted include 'capacity constraints' that point to a lack of comprehension and awareness about the SDGs and the evaluation techniques and frameworks that would be most suitable to analyse the SDGs; 'vague channels of information' that hamper the communication and dialogue on evaluative evidence on SDGs among governments and non-state actors; 'financing constraints' as VOPEs are financially highly constrained and unable to follow through on various SDG-related tasks; and the 'complexity of the SDG agenda' that refers to the many indicators and targets interpreted in different ways by multiple stakeholders.

The objectives of the conference were to (1) strengthen VOPEs to work with national governments to advance the evaluation agenda, (2) provide space for sharing experiences to enhance national evaluation capacities, (3) showcase the use of evaluative evidence in Africa and (4) contribute to the development of emerging evaluators. The conference also provided a convening space where new partnerships were established among the evaluation community on how to approach the evaluation of the SDGs.

The paper presentations were organised under 19 different 'strands', some of which included strands such as 'Evaluating Health in Africa', 'Made in Africa Evaluation', 'Evaluating Agriculture', 'Gender Equality and Equity Focused Evaluation' and 'Youth and Emerging Evaluators'.

Blaser-Mapitsa and Khumalo presented their paper, 'Diagnosing monitoring and evaluation capacity in Africa' as part of the Made in Africa Evaluation strand. This article shares lessons learnt from adapting and implementing a range of global tools in an African context. The article reviews CLEAR-Anglophone Africa's diagnostic tools, as well as global good practice diagnostic tools, and compares the strengths and weaknesses of each approach. It further looks at the implementation of specific tools in context and proposes components on the basis of these lessons. The article concludes that there is a need to ensure further research that will target the causal linkages between different elements of $M \& E$ systems. This will allow us to build an evidence base that can strengthen our theory of change around evaluation capacity development.

Goldman et al. submitted their paper that was part of the strand that focused on the role of government in evaluating the SDGs. The article documents the experience of three countries Benin, Uganda and South Africa - and summarises the progress made in deepening and widening their national evaluation systems and some of the cross-cutting lessons emerging at an early stage of the Twende Mbele partnership. Initial lessons include the importance of a central unit to drive the evaluation system, developing a national evaluation policy, prioritising evaluations through an evaluation agenda or plan and taking evaluation to subnational levels. The countries are exploring the role of non-state actors, and there are increasing moves to involve parliament. Key challenges include difficulty of getting a learning approach in government, capacity issues and ensuring follow-up. These lessons are being used to support other countries seeking to establish national evaluation systems, such as Ghana, Kenya and Niger. 
Tefera et al. presented their paper in the Evaluating Health in Africa strand. The article documents the experience from the Integrated Family Health Program in Ethiopia. It reflects on the use of continuous household surveys to generate timely data for annual programme outcome monitoring. It concludes that continuous household surveys and regular analysis of data are critical to identify challenges and bottlenecks so that timely adjustment of programme direction can be ensured and additional programme needs can be identified. It helps to produce outcome-level data for strategic decision-making on a timely basis and also helps to increase the value for money. Ssekamate presented his paper in the Evaluating Climate Change strand. The article entitled 'The role of M\&E in climate change mitigation and adaptation interventions in developing countries' discusses the critical role that M\&E can and should play in enhancing effectiveness of climate change mitigation and adaptation interventions in developing countries. This article presents key insights that practitioners need to design effective M\&E systems for climate change mitigation and adaptation.

Mahesh Patel was one of the keynote speakers at the conference. He submitted his input as an article entitled 'Human rights as a new development paradigm: A think piece on implications for monitoring and evaluation'. The article shares some of the conceptual and operational differences between the human rights approach and a 'development goals' approach in international development. It suggests that the human rights perspective reveals problems of which we were unaware and provides a complementary perspective, as social development earlier provided a complement to economic development. According to the article, the introduction of the human rights paradigm does not require the replacement of goal-based planning with something else.

Kamau et al. presented their paper as part of the Evaluating Agriculture strand. The article informs us that 'demonstration plots' are widely used in the seed industry to create awareness and promote improved seed use among smallholder farmers in sub-Saharan Africa. However, the magnitude of effects on farmers' adoption behaviour is less known. The results of the study showed that 'demonstration plots' were not effective, suggesting that more effective approaches should be explored. It may also be the case that the assessment was too early in the adoption cycle, in which case results after two more seasons of promotion will provide a better estimate of the effect.
Ssentamu's paper was part of the Evaluating Education strand and it deals with the assessment of quality provisioning of higher education in Uganda. The paper contends that higher education plays a key role in improving a country's social, cultural, political, economic and environmental domains. It explored good practices, challenges and prospects in the external peer M\&E of higher education institutions by the Uganda National Council for Higher Education. The study found that a shortage of human resources prepared to undertake and manage complex activities, like self-studies and peer M\&E, has become a serious challenge to building successful quality assurance programmes in Uganda. Alani's article, 'The role of human capital in the promotion of technological progress, economic growth and development in Africa: A case study of Kenya', was not presented at the AfrEA conference but was submitted to the journal for consideration before the conference event and has been included here. The paper evaluates the role of human capital in the promotion of technological progress, economic growth and development in Africa by focusing on the case of Kenya.

Book review: Zenda Ofir attended the conference and participated as a keynote speaker. She also provided a review of a book that was launched during the conference. The book Democratic Evaluation and Democracy: Exploring the Reality, edited by Donna Podems, is a good resource for exploring the reality of democratic evaluation and democracy. Zenda Ofir states that:

We should celebrate the rich content in this book that highlights the value of deep engagement with evaluation in the Global South from the perspective of both evaluation theory and practice. It will stimulate further intensive and rigorous examination of the contributions and value of different types of evaluation for countries at different and challenging stages of development. I trust that the book will become a required reading for all those interested in how evaluation is unfolding in democratic contexts and in countries where evaluation is still in the process of being institutionalised. By engaging forcefully with this important yet complex topic, Podems and her coauthors have made an invaluable contribution to the profession.

As was the practice at previous conferences, participants were invited to present their work via the medium of poster presentations. Posters were displayed outside the plenary venue throughout the 3 days of the conference. The posters were assessed on various criteria, such as visual communication, clarity of content, and the sense-making explanation of the poster presenter. The winning poster belonged to Mame Aissatou Mbaye of Senegal. 